\title{
Synapse Density Regulates Independence at Unitary Inhibitory Synapses
}

\author{
Linda S. Overstreet and Gary L. Westbrook \\ Vollum Institute, Oregon Health \& Science University, Portland, Oregon 97201
}

Neurotransmitter transporters may promote synapse specificity by limiting spillover between release sites. At GABAergic synapses, transport block prolongs synaptic responses when many inputs are activated, yet it is unclear whether transporters alter signaling by single axons. We found that unitary IPSCs generated by paired recordings between hippocampal interneurons and granule cells could be either prolonged or totally unaffected by block of GABA transporters. This variability was explained by the density of active release sites rather than the number of active sites. Prolongation by transport block required release from multiple sites and was enhanced by repetitive activation. Furthermore, transport-sensitive unitary IPSCs were accelerated when the release probability was reduced, indicating that cross talk prolonged the time course of IPSCs even when transport was intact. Our results suggest that the release site density regulates the degree of cross talk as well as the contribution of transporters to GABA clearance. Thus, interplay between release site density and transporter action determines the independence of unitary inhibitory synapses.

Key words: synaptic transmission; IPSC; transport; independence; density; NO711; dentate gyrus; $\mathrm{GABA}_{\mathrm{A}}$ receptor; granule cell

\section{Introduction}

The escape of fast neurotransmitters from the synaptic cleft has received considerable attention because it reduces the specificity of point-to-point transmission (for review, see Bergles et al., 1999), and in principle, it reduces the maximal information capacity of neuronal networks (Barbour, 2001). Synaptic cross talk can involve transmitter spillover that activates neighboring presynaptic or postsynaptic receptors (Isaacson et al., 1993; Asztely et al., 1997; Scanziani et al., 1997; Rossi and Hamann, 1998; Lozovaya et al., 1999; Diamond, 2001; Arnth-Jensen et al., 2002). However, any interaction that allows activity at one site to influence activity at surrounding sites reduces synaptic "independence." In general, such cross talk may occur between release sites from the same axon onto the same or distinct postsynaptic neurons, or, depending on spatiotemporal activity patterns, between different presynaptic and postsynaptic elements. Unfortunately, assessing the independence of individual release sites is technically daunting. It is also unclear whether the usual experimental stimulation, involving synchronous activation of multiple axons, is representative of the behavior of individual synapses. Thus the functional significance of cross talk has been controversial (Barbour and Häusser, 1997). At specialized excitatory synapses there is strong evidence that synchronous release from a large number of sites alters the glutamate transient via pooling between sites (Trussell et al., 1993; Barbour et al., 1994; Otis and Trussell, 1996; Silver et al., 1996). However, little is known about the indepen-

\footnotetext{
Received 0ct. 11, 2002; revised Jan. 16, 2003; accepted Jan. 17, 2003.

This work was supported by the Epilepsy Foundation through the generous support of the American Epilepsy Society and UCB Pharma Inc. (L.S.O.), National Institutes of Health Grant NS26494 (G.L.W.), and a grant from the Human Frontiers Science Program (G.L.W.). We thank Drs. Craig Jahr, Mathew Jones, and Jacques Wadiche for comments on this manuscript.

Correspondence should be addressed to Linda Overstreet, Vollum Institute, L474, Oregon Health \& Science University, 3181 SW Sam Jackson Park Road, Portland, OR 97201. E-mail: overstre@ohsu.edu.

Copyright $\odot 2003$ Society for Neuroscience $\quad 0270-6474 / 03 / 232618-09 \$ 15.00 / 0$
}

dence of the vast majority of synapses that are composed of a smaller number of release sites.

Neurotransmitter transporters could be a major determinant of synaptic independence by limiting the spread of transmitter beyond the cleft or by preventing access to adjacent sites. At inhibitory synapses, dramatic prolongations of large evoked synaptic responses occur when GABA transport is blocked (Roepstorff and Lambert, 1992, 1994; Thompson and Gähwiler, 1992; Isaacson et al., 1993; Draguhn and Heinemann, 1996). In contrast, smaller evoked currents and miniature IPSCs (mIPSCs) appear to be unaffected by GABA transport blockers, suggesting that transporters promote GABA clearance only during stimulation of a large number of synapses (Isaacson et al., 1993; Roepstorff and Lambert, 1994). This implies that GABA transport prevents synaptic cross talk during intense activity but plays a minor role at individual synapses.

Here we assessed the involvement of GABA transporters in regulating interactions between individual release sites at inhibitory synapses in the hippocampus. We used paired recordings in acute slices to examine unitary IPSCs (uIPSCs) on dentate granule cells evoked by stimulation of a single inhibitory axon. The time course of some uIPSCs was highly sensitive to transport block, whereas other uIPSCs were completely unaffected. Our results suggest that GABA transport is unnecessary for synaptic independence at unitary synapses composed of spatially distributed release sites because diffusion rapidly clears GABA at single sites. In our experiments, however, most of the synapses displayed some degree of cross talk that was limited by GABA transport.

\section{Materials and Methods}

Transverse hippocampal slices were prepared from postnatal day $(\mathrm{P})$ 13-15 Sprague Dawley rats and were incubated until use in a solution containing (in mM): $125 \mathrm{NaCl}, 25 \mathrm{NaHCO}_{3}, 2.5 \mathrm{KCl}, 1.25 \mathrm{NaH}_{2} \mathrm{PO}_{4}, 0.5$ $\mathrm{CaCl}_{2}, 2.5 \mathrm{MgCl}_{2}$, and $25 \mathrm{D}$-glucose, bubbled with $95 \% \mathrm{O}_{2}$ and $5 \% \mathrm{CO}_{2}$. During recordings, slices were perfused continuously with an extracellular solution containing (in mM): $125 \mathrm{NaCl}, 25 \mathrm{NaHCO}_{3}, 2.5 \mathrm{KCl}, 1.25$ 
$\mathrm{NaH}_{2} \mathrm{PO}_{4}, 2 \mathrm{CaCl}_{2}, 1 \mathrm{MgCl}_{2}$, and $25 \mathrm{D}$-glucose, bubbled with $95 \% \mathrm{O}_{2}$ and $5 \% \mathrm{CO}_{2}$ and maintained at $33 \pm 1{ }^{\circ} \mathrm{C}$. We made whole-cell recordings from pairs of interneurons and dentate granule cells. Presynaptic interneurons in the granule cell layer displayed little or no spike frequency accommodation in response to $0.6-1.0 \mathrm{nA}$ current injection. Presynaptic patch pipettes were filled with (in mM): $140 \mathrm{~K}$-gluconate, $10 \mathrm{EGTA}, 10$ HEPES, $2 \mathrm{Mg}_{2} \mathrm{ATP}, 0.5 \mathrm{NaGTP}$, and 20 phosphocreatine, adjusted to $\mathrm{pH}$ 7.3 and $310 \mathrm{mOsm}$ (3-5 M $\Omega$ resistance). Nearby granule cells were recorded using pipettes in which $\mathrm{KCl}$ was substituted for K-gluconate (1.5$2.5 \mathrm{M} \Omega$ resistance). Interneurons were maintained near $-60 \mathrm{mV}$ in current-clamp mode using an Axopatch 200A amplifier, and granule cells were voltage-clamped at $-70 \mathrm{mV}$ using an Axopatch $200 \mathrm{~B}$ amplifier (Axon Instruments). Currents were filtered at $2 \mathrm{kHz}$ and sampled at 10 $\mathrm{kHz}$. Series resistance was monitored throughout each experiment (4-12 $\mathrm{M} \Omega$ before $70-90 \%$ compensation); data were discarded if substantial increases were observed. Data are expressed as mean \pm SEM. Unless noted, statistical significance was determined by two-tailed $t$ tests or Mann-Whitney $U$ tests at the $p<0.05$ level.

CNQX $(10 \mu \mathrm{M})$ and the $\mathrm{GABA}_{\mathrm{B}}$ receptor antagonist CGP55845 (1-2 $\mu \mathrm{M})$ were included in all experiments. mIPSCs were recorded in TTX $(0.5$ $\mu \mathrm{M})$ and detected with the template matching procedure of Axograph 4.0 (Axon Instruments), using the sum of one rising $(\tau=200 \mu \mathrm{sec}$ ) and one falling ( $\tau=10 \mathrm{msec}$ ) exponential. The mIPSC decay time course was measured by averaging the subset of events separated by $\geq 100 \mathrm{msec}$. The decay of synaptic currents was fitted with the sum of two exponential functions and expressed as the weighted decay $(\tau)$ calculated from the equation $A_{\mathrm{x}} \tau_{1}+A_{\mathrm{x}} \tau_{2}$, where $A$ is the relative amplitude of each component and $\tau$ is its time constant. Focal stimulated IPSCs were evoked with a bipolar electrode (FHC, Bowdoinham, ME) placed in the granule cell layer. Rise times $(20-80 \%)$ were calculated from averaged IPSCs, except in the $\mathrm{Cd}^{2+}$ experiments in which they were was calculated from individual events. Failures detected by eye were excluded from all averaged responses. To avoid contamination by nonspecific changes in the current baseline, tonic currents associated with transport block were measured as changes in the SD of the mean current (Overstreet and Westbrook, 2001).

In initial experiments, uIPSCs had stable amplitudes (100 $\pm 8 \%$ of control) and rise times $(98 \pm 5 \%)$ during 20 min of recording $(n=11)$. Many recordings showed a slight time-dependent prolongation of the uIPSC decay such that the average weighted decay was significantly increased to $109 \pm 4 \%$ of control. In NO711, uIPSCs prolonged by $<30 \%$ were indistinguishable from control recordings and thus classified as NO711 insensitive, whereas uIPSCs prolonged to $>30 \%$ were classified as NO711 sensitive.

All drugs were dissolved in water or DMSO (final concentration $<0.1 \%$ ) and bath applied. Compounds were purchased from Sigma (St. Louis, MO), except that CNQX, AP5, and CGP55845 were purchased from Tocris Cookson (Ballwin, MO), and (NO-711) and SR95531 were purchased from Research Biochemicals (Natick, MA). SR95103 was a gift from Sanofi Recherche (Montpellier, France).

Biocytin $(0.2 \%)$ was included in the presynaptic pipette in most paired recordings. In some experiments, biocytin or Lucifer yellow (1 mM) was also included in the postsynaptic pipette. Tissue slices were fixed in $4 \%$ formaldehyde overnight $\left(4^{\circ} \mathrm{C}\right)$ and then incubated in permeabilizing (0.3\% Triton X-100) PBS solution containing Cy-5-conjugated streptavidin ( $1 \mu \mathrm{g} / \mathrm{ml}$; Jackson ImmunoResearch, West Grove, PA) for 1-2 d. Slices containing Lucifer yellow-filled cells were also incubated in rabbit anti-Lucifer yellow IgG (1:2500; Molecular Probes), with subsequent incubation in Oregon Green 488-labeled goat anti-rabbit IgG $(5 \mu \mathrm{g} / \mathrm{ml}$; Molecular Probes). The granule cell body layer was identified with propidium iodide staining (30 min incubation in $5 \mu \mathrm{g} / \mathrm{ml}$ ). Slices were washed in PBS and mounted with ProLong Antifade (Molecular Probes). Labeled cells were visualized with a confocal microscope (Noran Instruments, Middleton, WI).

\section{Results}

Prolongation of IPSCs by transport block depends on stimulus

In dentate granule cells, the GAT1-selective transport inhibitor NO711 $(20 \mu \mathrm{M})$ robustly prolonged all IPSCs evoked by focal, a evoked IPSC
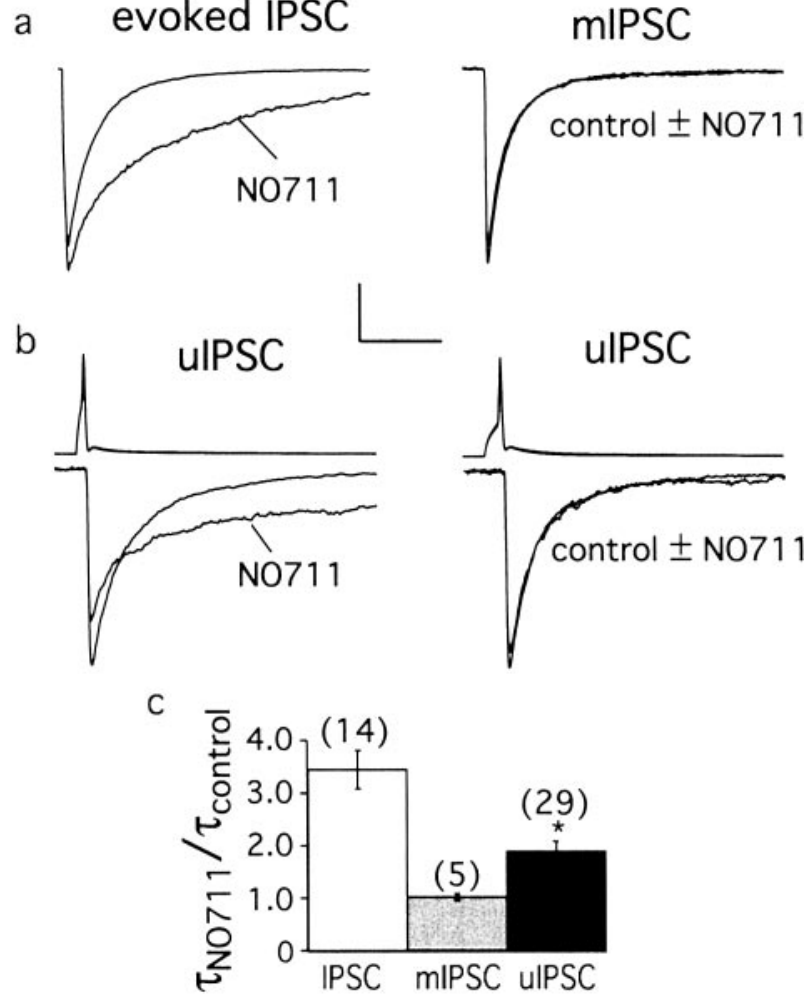

Figure 1. Prolongation of IPSCs by transport block depends on stimulus. $a$, Left, Block of GABA transporters with N0711 $(20 \mu \mathrm{M})$ prolonged IPSCs evoked by focal stimulation of the granule cell layer. Calibration: 500 pA, 50 msec. a, Right, Spontaneous mIPSCs recorded in TTX were unaffected by transport block. Calibration: $20 \mathrm{pA}, 20 \mathrm{msec}$. b, Unitary IPSCs (uIPSC) evoked by paired recordings of interneurons and granule cells were either prolonged or unaffected by transport block. Calibration: left, 120 pA, $20 \mathrm{msec}, 50 \mathrm{mV}$; right, $62 \mathrm{pA}, 20 \mathrm{msec}, 50 \mathrm{mV}$. c, The relative prolongation of IPSCs by transport block varied according to stimulus type. The number of experiments is shown in parentheses. The effect of transport block was quantified by the weighted decay $\tau$ in $\mathrm{N} 0711$ normalized to the weighted decay $\tau$ in control $\left(\tau_{\mathrm{N} 0711} / \tau_{\text {control }}\right)$.

multi-axon stimulation ( $346 \pm 35 \%$ of control; $n=14$ ) (Fig. $1 a$, left). The weighted decay was $22.5 \pm 2.0 \mathrm{msec}$ in control and $79.0 \pm 12 \mathrm{msec}$ in NO711. In contrast, mIPSCs, reflecting the spontaneous release of a single vesicle at an individual release site, were unchanged (Fig. 1a, right, Table 1). This discrepancy between mIPSCs and evoked IPSCs is similar to previous studies at other hippocampal synapses (Thompson and Gähwiler, 1992; Isaacson et al., 1993). The amplitudes of focal stimulated IPSCs and mIPSCs were not significantly altered $(85 \pm 6 \%$ of control, $n=14$, and $98 \pm 9 \%, n=5$, respectively; $p>0.1$ ).

To investigate the contribution of transporters to GABA clearance after release from a single axon, we recorded uIPSCs in pairs of interneurons and granule cells. We limited our recordings to fast-spiking interneurons with cell bodies in the granule cell layer. Action potentials triggered by brief current injections into the interneuron (typically $1 \mathrm{nA}$ for $2 \mathrm{msec}, 0.066 \mathrm{~Hz}$ ) evoked large uIPSCs with fast kinetics (Tables 1, 2). In contrast to focally stimulated IPSCs and mIPSCs, NO711 had highly variable effects on the time course of uIPSCs. NO711 prolonged the majority of uIPSCs ( $219 \pm 19 \%$ of control; $n=22$ of 29 ) (Fig. $1 b$, left), but a subset of uIPSCs was unaffected (109 $\pm 5 \%$ of control; $p>0.1$; $n=7$ of 29) (Fig. 1b, right). The weighted decay for all uIPSCs was $11.9 \pm 0.5 \mathrm{msec}$ in control and $23.6 \pm 2.9 \mathrm{msec}$ in NO711 $(n=$ $29 ; p=0.0001)$.

Previously we reported that a high concentration of NO711 $(100 \mu \mathrm{M})$ elevated ambient GABA, resulting in desensitization of 
Table 1. IPSC parameters

\begin{tabular}{|c|c|c|c|c|c|}
\hline & $\begin{array}{l}\text { Amplitude } \\
(\mathrm{pA})\end{array}$ & $\begin{array}{l}\text { Rise time } 20-80 \% \\
\text { (msec) }\end{array}$ & $\begin{array}{l}\text { Weighted decay } \tau \\
\text { (msec) }\end{array}$ & $\begin{array}{l}\text { N0711 decay } \tau \\
\text { (\% control) }\end{array}$ & $n$ \\
\hline mIPSCs & $52.2 \pm 3.5$ & $0.26 \pm 0.02$ & $9.6 \pm 1.2$ & $104 \pm 7^{a}$ & 11 \\
\hline ulPSCS & $450 \pm 75$ & $0.34 \pm 0.01$ & $11.9 \pm 0.5$ & $192 \pm 19^{b}$ & 29 \\
\hline Evoked IPSCS & $1015 \pm 105$ & $1.07 \pm 0.22$ & $22.5 \pm 2.0$ & $346 \pm 35^{b}$ & 14 \\
\hline
\end{tabular}

All values reflect mean \pm SEM.

${ }^{a} n=5$ for N0711 experiments.

${ }^{b}$ Different from control.

Table 2. Kinetic comparison of mIPSCs and uIPSCs

\begin{tabular}{|c|c|c|c|c|c|c|c|}
\hline & Control & & & N0711 & & & \\
\hline & $\tau_{\text {fast }}$ (msec) & $\tau_{\text {slow }}(\mathrm{msec})$ & $\%$ fast & $\tau_{\text {fast }}$ (msec) & $\tau_{\text {slow }}(\mathrm{msec})$ & $\%$ fast & $n$ \\
\hline mIPSCs & $5.4 \pm 0.6$ & $23.5 \pm 3.4$ & $73 \pm 7$ & $5.7 \pm 0.9$ & $26.1 \pm 4.0$ & $68 \pm 1$ & $11^{a}$ \\
\hline ulPSCs $s^{b}$ & $5.3 \pm 0.8$ & $25.6 \pm 3.0$ & $76 \pm 3$ & $5.4 \pm 0.5$ & $28.3 \pm 4.5$ & $76 \pm 3$ & 7 \\
\hline ulPSCs ${ }^{c}$ & $7.4 \pm 0.6^{d}$ & $34.0 \pm 3.3^{d}$ & $74 \pm 4$ & $9.1 \pm 0.6^{e}$ & $74.9 \pm 9.0^{e}$ & $70 \pm 3$ & 22 \\
\hline
\end{tabular}

All values reflect mean $\pm S E M$.

$a_{n}=5$ for N0711 experiments.

${ }^{b} \mathrm{~N} 0711$-insensitive.

'N0711-sensitive

${ }^{d}$ Different from mIPSCS.

eDifferent from control.

postsynaptic receptors and subsequent reduction in IPSCs (Overstreet et al., 2000; Overstreet and Westbrook, 2001). The lower concentration of NO711 used here $(20 \mu \mathrm{M})$ slightly increased the membrane noise (to $154 \pm 10 \%$ of control; $n=29$ ) and minimally reduced the uIPSC amplitude $(352 \pm 49 \mathrm{pA}$ in control compared with $300 \pm 42 \mathrm{pA}$ in NO711; $n=29 ; p=0.01)$. However, there was no correlation between changes in the peak amplitude and prolongation of the decay (data not shown).

\section{Prolongation by transport block is not correlated with IPSC amplitude}

It has been proposed that GABA transport limits the spread of GABA only when many synapses are active simultaneously (Thompson and Gähwiler, 1992; Isaacson et al., 1993). In our experiments, synchronous stimulation of multiple axons (i.e., focal stimulation) produced GABA release from a larger number of sites than activation of a single axon, as reflected in the larger amplitude of focally evoked IPSCs (Fig. $2 a$, left). However, there was no correlation between the amplitude of uIPSCs and the prolongation by NO711 (Fig. $2 a$, right). This was true even for the subset of synapses with the greatest prolongation $(>180 \% ; n=$ 8). Likewise, there was not a correlation between the amplitude of focally evoked IPSCs and prolongation by NO711 (data not shown).

Interneurons such as basket cells have profuse axonal arbors in the granule cell layer, with $\sim 10,000$ release sites that synapse with roughly 1000 granule cells and interneurons (Freund and Buzsáki, 1996). Although only a fraction of these release sites makes direct contact with a single granule cell, neighboring active sites could contribute GABA during transport block. We used paired-pulse stimulation to test whether a decrease in release probability, and thus in the number of active sites, reduced the effect of NO711. In control, the paired-pulse ratio was $0.74 \pm$ 0.03 , and the decay of the first and second uIPSC was similar (uIPSC $_{1} \tau=11.8 \pm 0.5 \mathrm{msec}$; IIPSC $_{2} \tau=11.2 \pm 0.6 \mathrm{msec} ; p=$ $0.2)$. NO711 did not alter the PPR $(0.75 \pm 0.05)$, and there was not a clear difference in the prolongation of the first and second response (prolonged to $193 \pm 18$ vs $170 \pm 11 \%$ of control, respectively; $p=0.1 ; n=29$ ) (Fig. 2b). However, when the NO711-
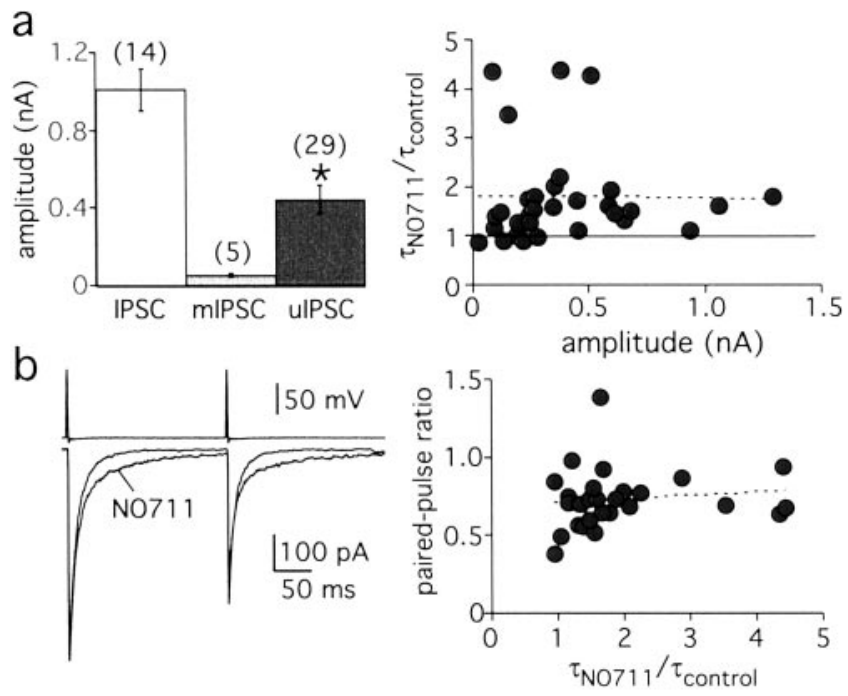

Figure 2. Prolongation by transport block is not correlated with IPSC amplitude. $a$, uIPSCS were smaller than focally stimulated IPSCs (left), but there was no correlation between the uIPSC amplitude and the prolongation by N0711 (right). Data from all uIPSCs are shown with a linear fit (dotted line). Solid line indicates no effect of transport block $\left(\tau_{\mathrm{N} 0711} / \tau_{\text {control }}=1\right) . b$, Left, At N0711-sensitive synapses, the second uIPSC in a paired-pulse protocol was slightly less prolonged by $N 0711$ compared with the first. Right, There was no correlation between the paired-pulse ratio and the prolongation by N0711 in individual paired recordings.

insensitive pairs were excluded from the analysis, we were able to unmask a significant effect of changing release probability. At NO711-sensitive synapses, the first uIPSC evoked in the pairedpulse protocol was more prolonged by NO711 than the second $(221 \pm 22$ vs $183 \pm 13 \%$, respectively; $n=22 ; p=0.04)$. This suggests that prolongation by transport block could be reduced by a decrease in the number of active release sites.

To determine whether high release probability conferred NO711 sensitivity, we compared the paired-pulse ratio and the failure rate at NO711-sensitive and -insensitive synapses. However, we were unable to detect a difference in either the failure rate $(0.07 \pm 0.03, n=22$ vs $0.09 \pm 0.04, n=7)$ or the paired-pulse ratio $(0.75 \pm 0.04, n=22$ vs $0.70 \pm 0.07, n=7)$. The lack of 

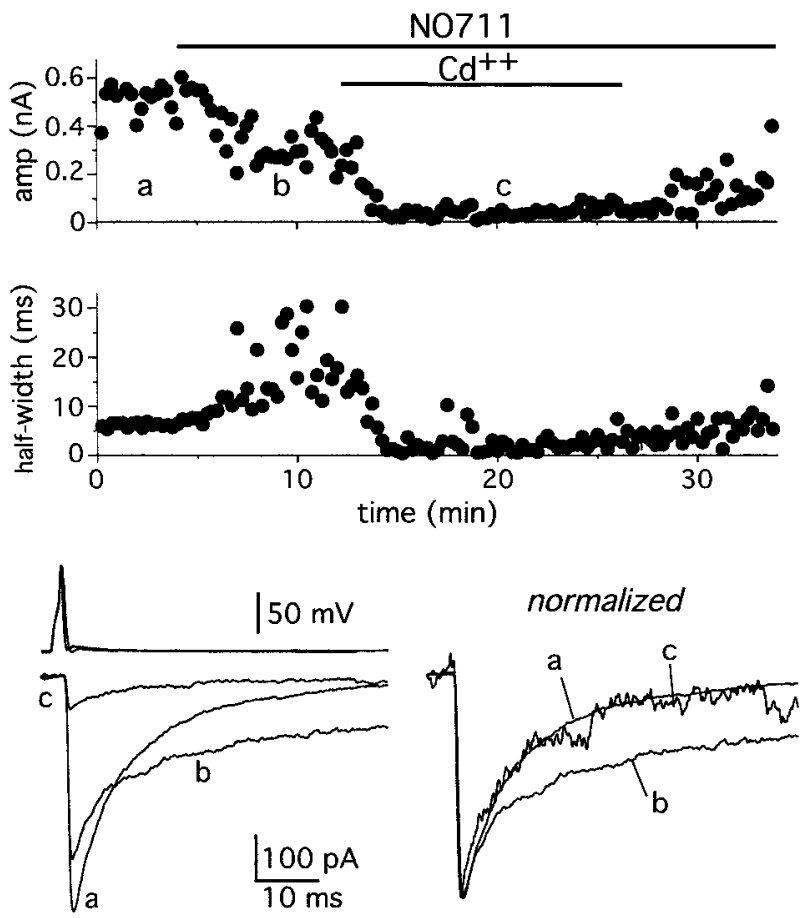

Figure 3. Prolongation of ulPSCs requires release from multiple sites. Top, An individual experiment showing changes in the ulPSC amplitude and half-width in N0711 and N0711 + $\mathrm{Cd}^{2+}(10 \mu \mathrm{M})$. Failures are included for illustration purposes. Bottom, Averaged uIPSCs from the time points indicated (failures excluded). N0711 prolonged the uIPSC. $\mathrm{Cd}^{2+}$ reduced the uIPSC amplitude to that of an mIPSC and blocked the prolongation $(n=4)$.

correlation between the paired-pulse ratio and NO711 sensitivity is shown in Figure $2 b$ (right). Together these results suggest that neither the initial number of active release sites nor the initial release probability determined NO711 sensitivity.

\section{Prolongation of uIPSCs by transport block requires release from multiple sites}

Although transporter action was not dependent on the absolute number of released vesicles, we wondered whether the density of active sites might be important. Transporters may contribute to GABA clearance only when transmitter pooling occurs, i.e., where cross talk between neighboring active sites slows clearance (Otis et al., 1996). Because diffusion sharply attenuates the concentration profile of neurotransmitter away from the release site, the propensity for interactions between sites must be dependent on their spatial proximity or density. Alternatively, one could postulate two populations of release sites, one that generates the majority of mIPSCs that are NO711 insensitive and a NO711sensitive population activated by exogenous stimulation. To distinguish between these possibilities, we examined the effect of transport block on release from a single site at a set of NO711sensitive unitary synapses. In control, NO711 prolonged the decay of these uIPSCs to $213 \pm 50 \%(n=4)$. We then reduced release probability with $\mathrm{Cd}^{2+}(5-10 \mu \mathrm{M})$ until the mean uIPSC amplitude (excluding failures, $74 \pm 12 \mathrm{pA} ; n=4$ ) (Fig. 3) was similar to the amplitude of an mIPSC. Thus most evoked events resulted from release at a single site, the ultimate reduction in density of active sites. As shown in Figure 3 (bottom panel), $\mathrm{Cd}^{2+}$ prevented the prolongation of these single-site uIPSCs (weighted decay in NO711, $26.7 \pm 6.9 \mathrm{msec}$; in $\mathrm{Cd}^{2+}+\mathrm{NO} 711,11.1 \pm 0.6$ $\mathrm{msec})$. Thus, transport block prolonged the synaptic current only
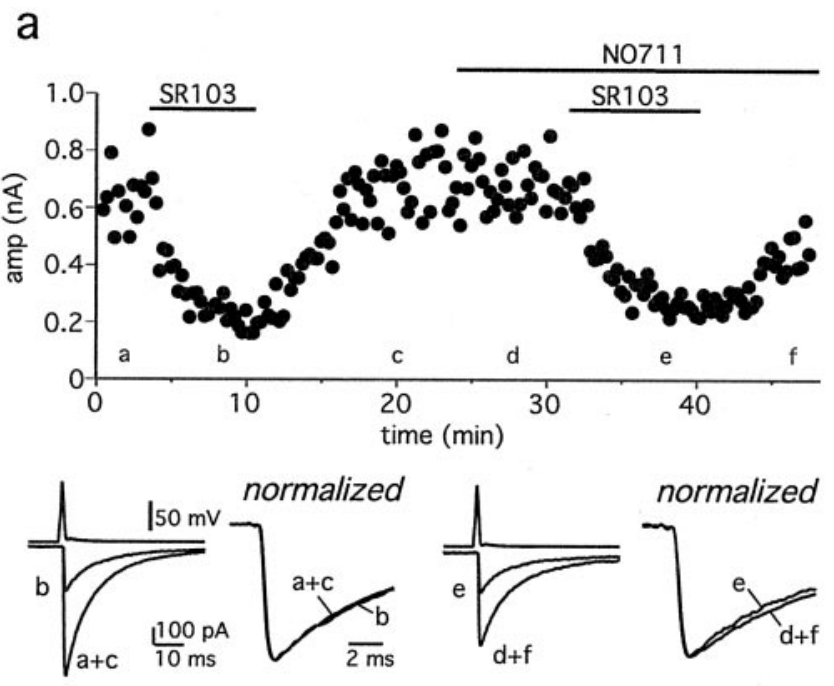

b

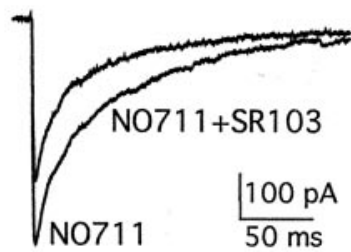

normalized

C

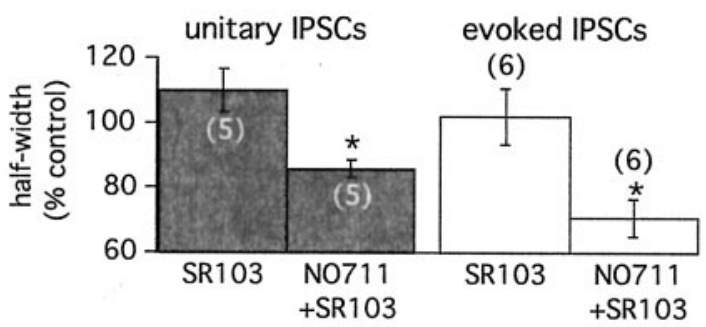

Figure 4. Transport block promotes spillover. $a$, The low-affinity competitive antagonist SR95103 (5 $\mu \mathrm{M})$ reduced the uIPSC amplitude to a similar extent in the absence and presence of N0711. Averaged uIPSCs from the time points indicated show that the antagonist accelerated the ulPSC decay only in N0711 $(n=5)$, suggesting that transport block promotes delayed activation of receptors by a low concentration of GABA. $b$, Using a similar protocol with IPSCs evoked by focal stimulation, SR95103 accelerated the decay of the multi-fiber IPSC when transport was blocked $(n=6)$. The stimulus artifacts are blanked for clarity. c, Comparison of the change in half-width for single-fiber unitary and multi-fiber evoked responses. In the absence of transport block, SR95103 had no effect on the uIPSC decay.

when there was release from multiple sites. These results argue against separate populations of NO711-sensitive and -insensitive sites and illustrate that dramatically reducing release site density alters the NO711 sensitivity of unitary synapses.

\section{Transport block promotes spillover}

At excitatory synapses, spillover-mediated currents can contribute to the slow decay of EPSCs (Lozovaya et al., 1999; Carter and Regehr, 2000). Because these spillover currents are generated by low concentrations of glutamate, this component of the EPSC is more sensitive to low-affinity antagonists (Diamond, 2001). We tested for a spillover component of uIPSCs using the low-affinity competitive $\mathrm{GABA}_{\mathrm{A}}$ receptor antagonist SR95103 (Jones et al., 2001). In five cell pairs, the antagonist was applied in the absence 
and presence of transport block (Fig. $4 a$ ). In control, SR95103 $(5 \mu \mathrm{M})$ reduced the peak amplitude to $38 \pm 2 \%$ of control and had no effect on the half-width of the uIPSC $(8.1 \pm 0.25$ vs $8.9 \pm 0.7 \mathrm{msec})$. Thus, a spillover-mediated component of the uIPSC was not detectable. Subsequent application of NO711 prolonged these uIPSCs to $163 \pm 16 \%$ of control $(n=5)$. In the presence of NO711, the low-affinity antagonist reduced the amplitude to the same extent (to $41 \pm 2 \%$ of control) but also reduced the half-width to $86 \pm 3 \%$ of control (10.6 \pm 0.9 vs $9.0 \pm 0.9 \mathrm{msec} ; p=$ $0.01)$. Thus, a slow component of the uIPSC produced by transport block was sensitive to the low-affinity antagonist, indicating that it was generated by a lower concentration of GABA. As expected, promoting GABA spillover by focal stimulation of IPSCs revealed a larger percentage reduction in the IPSC half-width by the low-affinity antagonist ( $34 \pm 6$ vs $24 \pm 6$ msec; $n=6$ ) (Fig. $4 b, c)$. These results suggest that transport block can produce spillover at unitary inhibitory synapses, and spillover is enhanced when the density of inputs is increased by synchronous activation of multiple axons.

\section{Repetitive stimulation}

In vivo, GABAergic basket cells fire in the gamma range (Penttonen et al., 1998). Such stimulus trains might be expected to increase pooling because vesicles are released sequentially at the same population of release sites. This was indeed the case. The weighted decay of synaptic current after a train of 10 action potentials $(100 \mathrm{~Hz})$ was prolonged to $370 \pm 84 \%$ of $\operatorname{control}(n=8)$. In some pairs, a GABAergic current persisted for hundreds of milliseconds in the presence of NO711, even when the single uIPSC was unaffected (Fig. 5a). The current decay after the stimulus train was also prolonged even in the absence of NO711 (to $148 \pm 16 \% ; p=0.04 ; n=8$ ) (Fig. 5c). It is unlikely that delayed vesicle release contributed to this delay because such release requires $>10$ stimuli and the accumulation of residual $\mathrm{Ca}^{2+}$ in the presynaptic terminal (Jensen et al., 2000; Lu and Trussell, 2000) that would be prevented in our recording conditions. In addition, we never observed delayed or asynchronous events in individual traces. Thus, interactions between sequential release events can alter the GABA transient and prolong the UIPSC decay even with transport intact.

A second uIPSC delivered immediately after the first unmasked a more prominent effect of transport block (to $201 \pm 25$ vs $153 \pm 8 \% ; n=8$ ) (Fig. $5 b$ ), although the second uIPSC had the same decay as the single IPSC with transport intact ( $13.6 \pm 0.6 \mathrm{vs}$ $14.4 \pm 0.9$ ). This suggests that residual GABA released by the first stimulus altered the GABA transient produced by the second stimulus. This interaction was evident at an interstimulus interval of $4.1 \pm 0.2 \mathrm{msec}(n=8)$. Thus, sequential release from the same population of sites can contribute to the apparent density of release sites, and the threshold for cross talk is lowered by transport block.
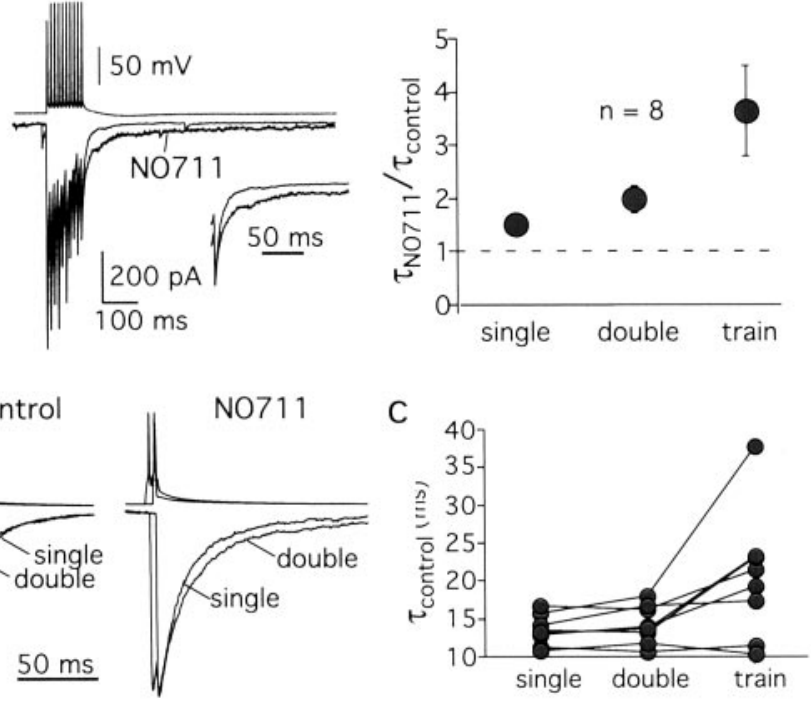

N0711

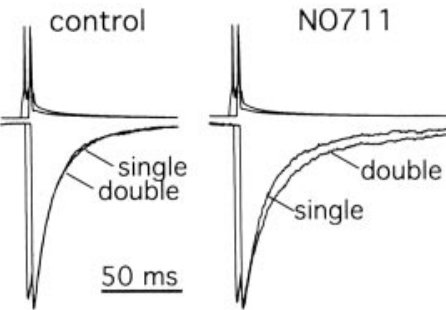

Figure 5. Repetitive stimulation increases functional synaptic density. a, Left, Transport block prolonged the decay of uIPSCS (10 action potentials at $100 \mathrm{~Hz}$ ), even in cases in which there was no effect on the single uIPSC. Right, unmasked greater prolongation by transportblock. Middle, The second uIPSC is normalized and aligned with the peak of the single the second response compared with the single. $c$, With transport intact, the decay of many uIPSCs was prolonged after a train of stimuli (mean prolongation to $148 \pm 16 \% ; n=8$ ).

\section{Sensitivity to transport block predicts the degree of synaptic independence}

The results presented thus far suggest that the density of active release sites determines the effect of transporters, and transport blockers, on inhibitory synaptic transmission. We directly tested this idea by comparing the independence of release sites in control conditions with the prolongation caused by transport block. Synapse independence was assessed by comparing the time course of uIPSCs in control with the time course after release probability was reduced using $\mathrm{Cd}^{2+} . \mathrm{Cd}^{2+}(10 \mu \mathrm{M})$ accelerated the uIPSC decay $(10.7 \pm 0.7$ to $8.5 \pm 0.5 \mathrm{msec} ; p=0.01 ; n=6)$ (Fig. $6 a, b$ ), indicating that under control conditions there was cross talk between release sites. Because $\mathrm{Cd}^{2+}$ may also reduce the number of vesicles released per site, multivesicular release may also contribute to the uIPSC decay (see Discussion). After independence was measured, $\mathrm{Cd}^{2+}$ was washed from the slice, and in control release conditions transporters were blocked with NO711 (Fig. 6a). There was a strong correlation between the acceleration of the uIPSC decay in $\mathrm{Cd}^{2+}$ and the relative prolongation produced by NO711 (Fig. 6c). Thus, the sensitivity of uIPSCs to transport block was inversely related to the degree of synaptic independence when uptake was intact.

We further examined this correlation by comparing the kinetics of uIPSCs that were sensitive to transport block with those that were unaffected. The decay of NO711-sensitive UIPSCs was significantly slower than NO711-insensitive uIPSCs $(p<0.007)$ (Table 2), although the amplitudes were similar (499 \pm 96 and $293 \pm 118 \mathrm{pA}$, respectively; $p>0.18$ ). This is consistent with cross talk contributing to the uIPSC time course at NO711sensitive synapses. Interestingly, the time course of NO711insensitive uIPSCs was similar to mIPSCs, suggesting that transmission at NO711-insensitive synapses was independent, equaling the sum of activity at the individual release sites. The faster kinetics of NO711-insensitive uIPSCs also argues against differential expression of GAT1 underlying the variable prolon- 

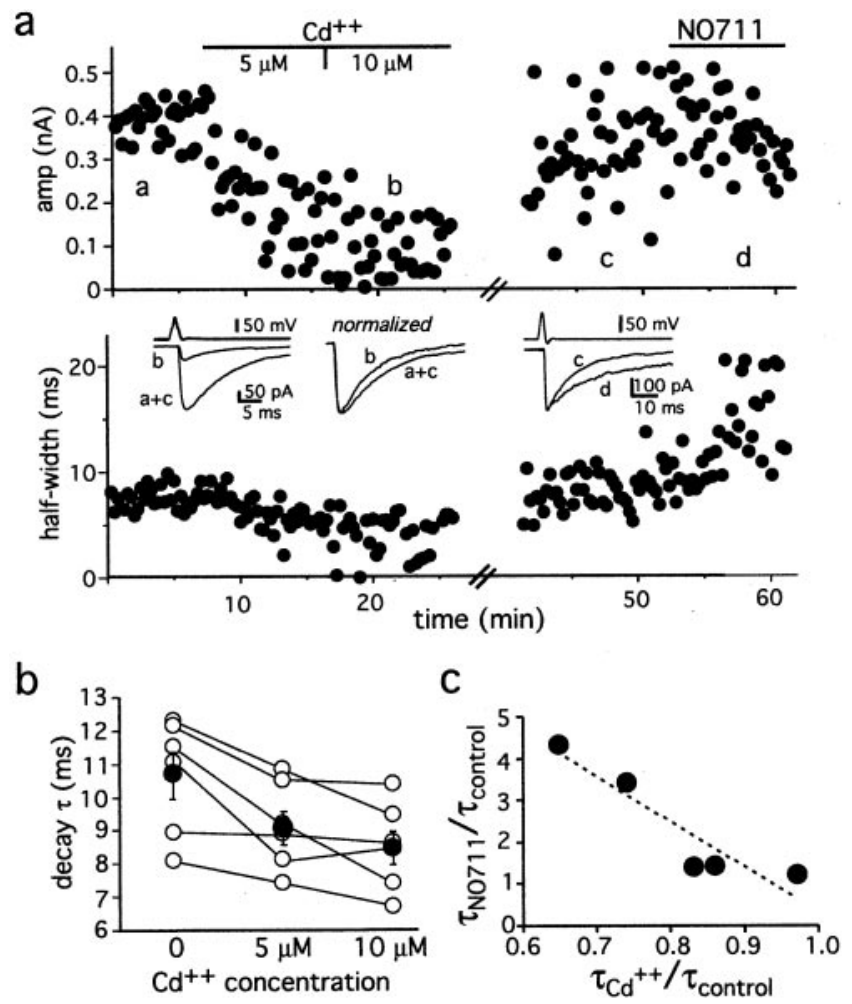

Figure 6. Correlation between synaptic cross talk and sensitivity to uptake block. $a, A n$ example of the reduction in uIPSC amplitude (top) and half-width (bottom) when release probability was reduced by $\mathrm{Cd}^{2+}$. When $\mathrm{Cd}^{2+}$ was washed from the slice, this uIPSC was robustly prolonged by transport block. Insets illustrate averaged responses (failures excluded) from the indicated time points. $b, \mathrm{Cd}^{2+}$ reduced the weighted decay of most uIPSCs. Individual experiments are connected by lines, and solid symbols indicate the mean $\pm S E M . \mathrm{Cd}^{2+}$ also reduced the uIPSC rise time from $341 \pm 50$ to $256 \pm 23 \mu \mathrm{sec}(n=6 ; p=0.04$; one-tailed $t$ test), consistent with a reduction in release asynchrony (Kraushaar and Jonas, 2000). ulPSCs recorded in $0 \mathrm{Cd}^{2+}$ reflect averaged responses from control and wash periods. $c$, There was a strong correlation ( $r=0.93 ; p=0.024)$ between the acceleration in the uIPSC decay in $\mathrm{Cd}^{2+}$ and the prolongation of the decay produced by subsequent transport block.

gation by NO711 (Engel et al., 1998), because it indicates that transport activity did not contribute to their rapid decay. Together these results are consistent with the idea that independence at unitary synapses varies depending on the density of release sites. Synapses composed of widely distributed release sites have fast decay kinetics that are unaffected by changes in release probability and, like mIPSCs, are insensitive to transport block. Conversely, synapses composed of higher density release sites have delayed clearance of transmitter that contributes to uIPSCs with slower decays that are sensitive to release probability and transport block.

\section{Morphological correlate to synapse density}

In the dentate, two subtypes of fast-spiking interneurons have cell bodies in the granule cell layer: basket cells and axo-axonic cells (Freund and Buzsáki, 1996). The distribution of their axon terminals on target cells is the primary anatomical difference between these cell types. Although both make approximately the same number of contacts on a granule cell, basket cell release sites are spread across the soma and proximal dendrites, whereas axoaxonic release sites are clustered on the axon initial segment (Buhl et al., 1994a; Megías et al., 2001). If there were a morphological correlate to the functional release site density suggested by the $\mathrm{Cd}^{2+}$ experiments, uIPSCs generated by axo-axonic cells should be more sensitive to transport block than uIPSCs generated by basket cells. Post hoc examination of filled cells revealed that most interneurons had characteristics of basket cells, including pyramidal-shaped cell bodies located close to the hilar border, prominent apical and basal dendrites, and a dense axonal arbor in the outer half of the granule cell layer (Freund and Buzsáki, 1996). However, a few interneurons had characteristics consistent with axo-axonic cells, including polygonal cell bodies, less pronounced or absent basal dendrites, and axonal projections into the hilus with axonal varicosities oriented parallel to the mossy fibers (Soriano et al., 1990; Freund and Buzsáki, 1996). Morphological identification of both presynaptic and postsynaptic cells was possible in a few cases. Putative synaptic contacts on the granule cell soma and dendrites confirm the identity of the basket cell illustrated in Figure $7 a$. Putative synaptic contacts on the axon of the granule cell are consistent with the identity of the axo-axonic cell illustrated in Figure $7 b$. Consistent with previous reports, basket cells and axo-axonic cells had similar membrane properties (Buhl et al., 1994b, 1995). Synaptic currents evoked by basket cells and axo-axonic cells also had similar paired-pulse ratios $(0.65 \pm 0.04, n=12$, vs $0.78 \pm 0.06, n=4 ; p>0.1)$ and failure rates $(0.07 \pm 0.03, n=12$ vs $0.03 \pm 0.02, n=4 ; p>0.2)$. However, uIPSCs evoked by axo-axonic cells were more prolonged by NO711 than uIPSCs evoked by basket cells (to $295 \pm$ $56 \%$ of control, $n=4$, compared with $131 \pm 8 \%$ of control, $n=$ $12 ; p<0.001$ ) (Fig. 7a3,b3). The observation that some basket cell-evoked uIPSCs were moderately prolonged by NO711 suggests that release site density, rather than cell type, underlies the differential sensitivity to transport block.

\section{Discussion}

Our results indicate that independence varies at interneurongranule cell unitary synapses as a result of differences in the density of release sites and that transporters normally limit interactions between closely spaced sites. Conversely, synaptic responses generated at single or widely distributed release sites are unaffected by transport block, indicating that GABA clearance under these circumstances occurs mainly by diffusion.

\section{Heterogeneity of hippocampal interneurons}

The diversity of GABAergic interneurons in the hippocampus reflects the multiple functions of synaptic inhibition within the hippocampal network. Interneuron subtypes can be distinguished by several criteria, such as morphology, physiology, and immunohistochemistry (Freund and Buzsáki, 1996). Although overlap between these features makes it impossible to segregate interneurons into a few well defined groups (Parra et al., 1998), it is becoming increasingly clear that the connectivity pattern provides insight into the physiological functions of each subtype. For example, interneurons that innervate pyramidal cell dendrites regulate the integration of EPSPs and the generation of $\mathrm{Ca}^{+}$dependent action potentials, whereas somatic-axonal inhibition controls the local generation of $\mathrm{Na}^{+}$-dependent action potentials (Miles et al., 1996; Pouille and Scanziani, 2001).

Here we show that variability in synaptic independence represents another layer of heterogeneity in interneuron characteristics. We recorded from fast-spiking interneurons with axonal projections in the granule cell layer, corresponding to basket cells and axo-axonic cells. GAT1 is highly expressed in axon terminals of these interneurons (Ribak et al., 1996). However, unitary synapses from axo-axonic interneurons were more sensitive to transport block than uIPSCs arising from basket cell interneurons. 
Several lines of evidence suggest that this difference was caused by a higher average density of release sites for axo-axonic cells rather than subtype-specific differences in synaptic function. First, in CA1 pyramidal cells the density of inhibitory sites on the axon initial segment is estimated to be $50 \%$ higher than on the soma ( 0.68 vs 0.45 synapses per micrometer) (Megías et al., 2001). Simulations of neurotransmitter diffusion suggest that intersynaptic distances in this range are a crucial variable in determining the extent of cross talk (Rusakov et al., 1999). The restricted localization of axo-axonic terminals on the granule cell axon initial segment (Soriano et al., 1990; Buhl et al., 1994b) is thus expected to increase interactions between these sites. Second, the sensitivity to transport block appeared to be a continuum with axoaxonic cell uIPSCs at one end of the spectrum. We predict that the variability in NO711 sensitivity of basket cell uIPSCs may reflect variability in release site density. Third, NO711 sensitivity was abolished by significantly reducing the density of active release sites. This observation, along with the insensitivity of mIPSCs to NO711, indicates that transporters do not influence synaptic responses at individual release sites and that sensitivity to transport block requires release from multiple sites. Finally, the correlation between the acceleration of the UIPSC decay at low release probability and the sensitivity to NO711 strongly suggest that these properties predict the existence of closely spaced release sites.

\section{Determinants of transporter}

\section{involvement in synaptic function}

Our results suggest that interactions between GABA released at multiple sites can prolong the synaptic response even with transport intact. A similar relationship between the quantal content and the decay of the synaptic current occurs at specialized excitatory synapses (Otis and Trussell, 1996; Silver et al., 1996, DiGregorio et al., 2002) and when large numbers of synapses are activated simultaneously (Roepstorff and Lambert, 1994; Takahashi et al., 1995; Arnth-Jensen et al., 2002). Using a low-affinity antagonist, we were unable to detect a contribution of spillover unless transport was blocked, suggesting that the slowing of the unitary IPSC decay at normal release probability is caused by delayed clearance. Such alterations in the GABA transient could prolong uIPSCs by promoting entry into fast desensitized states (Jones and Westbrook, 1995). Regardless of the specific mechanisms involved, the correlation between the acceleration of the uIPSC with $\mathrm{Cd}^{2+}$ and the prolongation of the UIPSC decay by transport block reflects the shared requirement for a high density of release sites. Synapses composed of closely spaced release sites are mostly likely to have GABA clearance impaired by pooling and are also most likely to allow spillover activation of neighboring receptors when transport is blocked.

With transport blocked, a low-affinity antagonist accelerated the decay of uIPSCs, consistent with activation of $\mathrm{GABA}_{\mathrm{A}}$ receptors by a small and slow component of the GABA transient. Such acceleration indicates that the slow transient results from activation of previously inactive receptors (Diamond, 2001). The receptors could be either synaptic or extrasynaptic. Reducing the release probability prevented the prolongation, suggesting that pooling of transmitter released from multiple sites was required to reach sufficient concentrations for receptor activation (ArnthJensen et al., 2002). This may account for the minimal effect of transport blockers on the decay of IPSCs in cell cultures (Oh and Dichter, 1994; Hill et al., 1998; Overstreet et al., 2000). We suspect that the extrasynaptic space is relatively exposed in cell cultures, thereby preventing cooperation between sites. These observations corroborate the general idea that transporters limit transmitter spread outside and between synapses. Our results demonstrate that such interactions occur after activation of a single inhibitory axon.

Our interpretation that differences in synaptic density underlie the variable effects of transport block assumes that changes in release probability alter the number of active release sites. If multivesicular release (Tong and Jahr, 1994a; Auger et al., 1998; Wadiche and Jahr, 2001; Oertner et al., 2002) occurs at these synapses, manipulations that reduce release probability would 
reduce the number of vesicles per site as well as the density of active sites. Because the propensity for multivesicular release is related to release probability (Wadiche and Jahr, 2001; Oertner et al., 2002), a reduction in multivesicular release could have contributed to the acceleration of the UIPSC decay when release probability was reduced. However, it is unlikely that multivesicular release confers NO711 sensitivity because we were unable to detect differences in initial release probability between NO711sensitive and -insensitive uIPSC [but see Kraushaar and Jonas (2000)]. In addition, there was little variability in the average peak GABA concentration as measured by SR95103 block in uIPSCs with differing NO711 sensitivities (experiments shown in Fig. 4).

Neurotransmitter transporters may regulate the duration of time that synaptic receptors are exposed to a high concentration of transmitter. This could alter the occupancy of receptors without changing the time course of the synaptic current (Tong and Jahr, 1994b). If synaptic $\mathrm{GABA}_{\mathrm{A}}$ receptors are unsaturated, blocking GABA transport could increase the IPSC amplitude by increasing the number of activated receptors. There is evidence that $\mathrm{GABA}_{\mathrm{A}}$ receptors on granule cells are not saturated at room temperature (Hajos et al., 2000 ), but the occupancy at $\sim 34^{\circ}$ is unknown. Although in individual experiments the uIPSC amplitude could be augmented in NO711, on average, the uIPSC amplitude was slightly reduced rather than increased. The interpretation of this result is complicated because inhibition of GABA transport can elevate ambient GABA (Overstreet and Westbrook, 2001; Nusser and Mody, 2002) and reduce IPSCs by postsynaptic receptor desensitization (Overstreet et al., 2000).

\section{Utility of independence at inhibitory synapses}

Oscillations produced by networks of inhibitory interneurons provide a timing signal that promotes temporal coincidence between principal cells (Buzsáki and Chrobak, 1995). During oscillations, a significant proportion of interneurons fire within each cycle. Cooperative GABA release from many interneurons during in vitro oscillations produces spillover activation of postsynaptic $\mathrm{GABA}_{\mathrm{B}}$ receptors away from the site of release (Scanziani, 2000). Likewise, we predict that synchronous activity in basket cells and axo-axonic cells that converge onto individual granule cells will facilitate cross talk through $\mathrm{GABA}_{\mathrm{A}}$ receptors and increase the contribution of transporters to GABA clearance. The expected degradation of synaptic independence during oscillations raises the question of whether independence at inhibitory synapses serves any function. It is likely that synapse efficacy and reliability (Kraushaar and Jonas, 2000) take precedence over precise timing at somatic inhibitory synapses onto principal cells. Here, the rapid initiation of feedforward inhibition sets a narrow time window within which excitatory inputs can summate to reach firing threshold (Pouille and Scanziani, 2001). Furthermore, millisecond differences in the duration of inhibitory conductances are unlikely to influence the synchronization of principal cells at theta frequency (4-7 Hz) (Cobb et al., 1995). Thus, the density of perisomatic release sites, particularly on the axon initial segment, may reflect the functional requirement of efficacy rather than specificity.

\section{References}

Arnth-Jensen N, Jabaudon D, Scanziani M (2002) Cooperation between independent hippocampal synapses is controlled by glutamate uptake. Nat Neurosci 5:325-331.

Asztely F, Erdemli G, Kullman DM (1997) Extrasynaptic glutamate spillover in the hippocampus: dependence on temperature and the role of active glutamate uptake. Neuron 18:281-293.

Auger C, Kondo S, Marty AJ (1998) Multivesicular release at single func- tional synaptic sites in cerebellar stellate and basket cells. J Neurosci 18:4532-4547.

Barbour B (2001) An evaluation of synapse independence. J Neurosci 21:7969-7984.

Barbour B, Häusser M (1997) Intersynaptic diffusion of neurotransmitter. Trends Neurosci 20:377-384.

Barbour B, Keller BU, Llano I, Marty A (1994) Prolonged presence of glutamate during excitatory synaptic transmission to cerebellar Purkinje cells. Neuron 12:1331-1343.

Bergles DE, Diamond JS, Jahr CE (1999) Clearance of glutamate inside the synapse and beyond. Curr Opin Neurobiol 9:293-298.

Buhl EH, Halasy K, Somogyi P (1994a) Diverse sources of hippocampal unitary inhibitory postsynaptic potentials and the number of synaptic release sites. Nature 368:823-828.

Buhl EH, Han Z-S, Lorinczi Z, Stezhka VV, Karnup SV, Somogyi P (1994b) Physiological properties of anatomically identified axo-axonic cells in the rat hippocampus. J Neurophysiol 71:1289-1307.

Buhl EH, Cobb SR, Halasy K, Somogyi P (1995) Properties of unitary IPSPs evoked by anatomically identified basket cells in the rat hippocampus. Eur J Neurosci 7:1989-2004.

Buzsáki G, Chrobak JJ (1995) Temporal structure in spatially organized neuronal ensembles: a role for interneuronal networks. Curr Opin Neurobiol 5:504-510.

Carter AG, Regehr WG (2000) Prolonged synaptic currents and glutamate spillover at the parallel fiber to stellate cell synapse. J Neurosci 20:4423-4434.

Cobb SR, Buhl EH, Halasy K, Paulsen O, Somogyi P (1995) Synchronization of neuronal activity in hippocampus by individual GABAergic interneurons. Nature 378:75-78.

Diamond JS (2001) Neuronal glutamate transporters limit activation of NMDA receptors by neurotransmitter spillover on CA1 pyramidal cells. J Neurosci 21:8328-8338.

DiGregorio DA, Nusser Z, Silver RA (2002) Spillover of glutamate onto synaptic AMPA receptors enhances fast transmission at a cerebellar synapse. Neuron 35:521-533.

Draguhn A, Heinemann U (1996) Different mechanisms regulate IPSC kinetics in early postnatal and juvenile hippocampal granule cells. J Neurophysiol 76:3983-3993.

Engel D, Schmitz D, Gloveli T, Frahm C, Heinemann U, Draguhn A (1998) Laminar difference in GABA uptake and GAT-1 expression in rat CA1. J Physiol (Lond) 512:643-649.

Freund TF, Buzsáki G (1996) Interneurons of the hippocampus. Hippocampus 6:347-470.

Hajos N, Nusser Z, Rancz EA, Freund TF, Mody I (2000) Cell type- and synapse-specific variability in synaptic $\mathrm{GABA}_{\mathrm{A}}$ receptor occupancy. Eur J Neurosci 12:810-818.

Hill MW, Reddy PA, Covey DF, Rothman SM (1998) Contribution of subsaturating GABA concentrations to IPSCs in cultured hippocampal neurons. J Neurosci 18:5103-5111.

Isaacson JS, Solis JM, Nicoll RA (1993) Local and diffuse synaptic actions of GABA in the hippocampus. Neuron 10:165-175.

Jensen K, Lambert JD, Jensen MS (2000) Tetanus-induced asynchronous GABA release in cultured hippocampal neurons. Brain Res 880:198-201.

Jones MV, Westbrook GL (1995) Desensitized states prolong GABA $_{\mathrm{A}}$ channel responses to brief agonist pulses. Neuron 15:181-191.

Jones MV, Jonas P, Sahara Y, Westbrook GL (2001) Microscopic kinetics and energetics distinguish $\mathrm{GABA}_{\mathrm{A}}$ receptor agonists from antagonists. Biophys J 81:2660-2670.

Kraushaar U, Jonas P (2000) Efficacy and stability of quantal GABA release at a hippocampal interneuron-principal neuron synapse. J Neurosci 20:5594-607.

Lozovaya NA, Kopanitsa MV, Boychuk YA, Krishtal OA (1999) Enhancement of glutamate release uncovers spillover-mediated transmission by $\mathrm{N}$-methyl-D-aspartate receptors in the rat hippocampus. Neuroscience 91:1321-1330.

Lu T, Trussell LO (2000) Inhibitory transmission mediated by asynchronous transmitter release. Neuron 26:683-694.

Megías M, Emri ZS, Freund TF, Gulyás AI (2001) Total number and distribution of inhibitory and excitatory synapses on hippocampal CA1 pyramidal cells. Neuroscience 102:527-540. 
Miles R, Toth K, Gulyas AI, Hajos N, Freund TF (1996) Differences between somatic and dendritic inhibition in the hippocampus. Neuron $16: 815-823$.

Nusser Z, Mody I (2002) Selective modulation of tonic and phasic inhibitions in dentate gyrus granule cells. J Neurophysiol 87:2624-2628.

Oertner TG, Sabatini BL, Nimchinsky EA, Svoboda K (2002) Facilitation at single synapses probed with optical quantal analysis. Nat Neurosci 5:657-664

Oh D-J, Dichter MA (1994) Effect of a $\gamma$-aminobutyric acid uptake inhibitory, NNC-711, on spontaneous postsynaptic currents in cultured rat hippocampal neurons: implications for anti-epileptic drug development. Epilepsia 35:426-430.

Otis TS, Trussell LO (1996) Inhibition of transmitter release shortens the duration of the excitatory synaptic current at a calyceal synapse. J Neurophysiol 76:3584-3588.

Otis TS, Wu YC, Trussell LO (1996) Delayed clearance of transmitter and the role of glutamate transporters at synapses with multiple release sites. J Neurosci 16:1634-1644.

Overstreet LS, Westbrook GL (2001) Paradoxical reduction of synaptic inhibition by vigabatrin. J Neurophysiol 86:596-603.

Overstreet LS, Jones MV, Westbrook GL (2000) Slow desensitization regulates the availability of synaptic $\mathrm{GABA}_{\mathrm{A}}$ receptors. J Neurosci 20: 7914-7921.

Parra P, Gulyas AI, Miles R (1998) How many subtypes of inhibitory cells in the hippocampus? Neuron 20:983-993.

Penttonen M, Karmondi A, Acsady I, Buzsáki G (1998) Gamma frequency oscillation in the hippocampus of the rat: intracellular analysis in vivo. Eur J Neurosci 10:718-728.

Pouille F, Scanziani M (2001) Enforcement of temporal fidelity in pyramidal cells by somatic feed-forward inhibition. Science 293:1159-1163.

Ribak CE, Tong WM, Brecha NC (1996) GABA plasma membrane transporters, GAT-1 and GAT-3, display different distributions in the rat hippocampus. J Comp Neurol 367:595-606.

Roepstorff A, Lambert JD (1992) Comparison of the effect of the GABA uptake blockers, tiagabine and nipecotic acid, on inhibitory synaptic efficacy in hippocampal CA1 neurons. Neurosci Lett 146:131-134.

Roepstorff A, Lambert JD (1994) Factors contributing to the decay of the stimulus-evoked IPSC in rat hippocampal CA1 neurons. J Neurophysiol 72:2911-2926.

Rossi DJ, Hamann M (1998) Spillover-mediated transmission at inhibitory synapses promoted by high affinity alpha6 subunit $\mathrm{GABA}_{\mathrm{A}}$ receptors and glomerular geometry. Neuron 20:783-795.

Rusakov DA, Kullmann DM, Stewart MG (1999) Hippocampal synapses: do they talk to their neighbours? Trends Neurosci 22:382-388.

Scanziani M (2000) GABA spillover activates postsynaptic GABA $_{B}$ receptors to control rhythmic hippocampal activity. Neuron 25:673-681.

Scanziani M, Salin PA, Vogt KE, Malenka RC, Nicoll RA (1997) Usedependent increases in glutamate concentration activate presynaptic metabotropic glutamate receptors. Nature 385:630-634.

Silver RA, Cull-Candy SG, Takahashi T (1996) Non-NMDA glutamate receptor occupancy and open probability at a rat cerebellar synapse with single and multiple release sites. J Physiol (Lond) 494:231-250.

Soriano E, Nitsch R, Frotscher M (1990) Axo-axonic chandelier cells in the rat fascia dentate: Golgi-electron microscopy and immunocytochemical studies. J Comp Neurol 293:1-25.

Takahashi M, Kovalchuk Y, Attwell D (1995) Presynaptic and postsynaptic determinants of EPSC waveform at cerebellar climbing fiber and parallel fiber to Purkinje cell synapses. J Neurosci 15:5693-5702.

Thompson SM, Gähwiler BH (1992) Effects of the GABA uptake inhibitor tiagabine on inhibitory synaptic potentials in rat hippocampal slice cultures. J Neurophysiol 67:1698-1701.

Tong G, Jahr CE (1994a) Multivesicular release from excitatory synapses of cultured hippocampal neurons. Neuron 12:51-59.

Tong G, Jahr CE (1994b) Block of glutamate transporters potentiates postsynaptic excitation. Neuron 13:1195-1203.

Trussell LO, Zhang S, Raman IM (1993) Desensitization of AMPA receptors on multiquantal neurotransmitter release. Neuron 10:1185-1196.

Wadiche JI, Jahr CE (2001) Multivesicular release at climbing fiberPurkinje cell synapses. Neuron 32:301-313. 